\title{
ATHANASIUS AND THE BOOK OF WISDOM
}

One of the main characteristics of Athanasius' writings ${ }^{1}$ is their continuous drawing on Scripture, which is amazing in quantity, creativity and originality. Yet the bishop of Alexandria was not so much an exegete pur sang. Unlike Origen or Augustine, Athanasius did not write running commentaries on the Bible. His use of Scripture has rather a fragmentary character ${ }^{2}$. Quotations from very different books are often brought together to support the point he wants to make ${ }^{3}$. Thus far a synthetic study of Athanasius' use of Scripture has not been been made but in the past decade quite a few articles dealing with his exegesis of a particular book or passage have been published ${ }^{4}$.

This article discusses Athanasius' borrowings from the Book of Wis$\mathrm{dom}^{5}$. There are three reasons why we choose this book. First of all there

1. We use the following abbreviations: $C G$ (Contra Gentes); DIV (De Incarnatione Verbi); $C A$ (Contra Arianos); FL (Festal Letters).

2. See the following general contributions on Athanasius' use of the Bible: B. DE LA MARGerie, Introduction à l'histoire de l'exégèse. I. Les Pères Grecs et orientaux, Paris, 1980, pp. 137-165; C. KANNENGIESSER, La Bible et la crise arienne, in C. MONDESERT (ed.), Le monde grec ancien et la Bible (BTT, 1), Paris, 1984, pp. 301-312; C. STEAD, Athanasius als Exeget, in J. VAN OORT - U. WICKERT (eds.), Christliche Exegese zwischen Nicaea und Chalcedon, Kampen, 1992, pp. 174-184; C. Kannengiesser, Athanasius von Alexandrien als Exeget, in G. SCHÖLGEN - C. SCHOLten (eds.), Stimuli. Exegese und ihre Hermeneutik in Antike und Christentum. Festschrift für Ernst Dassmann (JAC Ergänzungsband, 23), Münster, 1996, pp. 336-343.

3. See, e.g., the analysis by C. KANNENGIESSER, Les citations bibliques du traité athanasien "Sur l'Incarnation du Verbe" et les "Testimonia", in A. BENOIT - P. PRIGENT (eds.), La Bible et les Pères. Colloque de Strasbourg (1 ${ }^{e r}-3$ octobre 1969), Paris, 1971, pp. 135-160.

4. Articles discussing Athanasius' use of one particular book or passage: H.R. SMYTHE, The Interpretation of Amos 4,13 in Athanasius and Didymus, in JTS 1 (1950) 158-168; V.O. Marangoni, Juan 10,30 en la argumentacion escrituristica de san Atanasio, in Stromata 26 (1970) 3-57; C. KANNENGIESSER, Le recours au Livre de Jérémie chez Athanase d'Alexandrie, in J. FonTAINE - C. KANNENGIESSER (eds.), Epektasis. Mélanges patristiques offerts au Cardinal Jean Daniélou, Paris, 1972, pp. 317-327; A. MEREDITH, Proverbes VIII,22 chez Origène, Athanase, Basile et Grégoire de Nysse, in C. KANNENGIESSER (ed.), Politique et théologie chez Athanase d'Alexandrie (Théologie historique, 27), Paris, 1974, pp. 349-359; A.L. KolP, Partakers of the Divine Nature. The Use of II Peter 1,4 by Athanasius, in Studia Patristica 17/3 (1982) 1018-1023; E. Cattaneo, La bestemmia contro lo Spirito Santo (Mt. 12,31-32) in S. Atanasio, in Studia Patristica 21 (1989) 420-425; M. CANEVET, La théologie au secours de l'herméneutique biblique: l'exégèse de Phil. 2 et du Ps. 44 dans le contra Arianos I, 37-52 d'Athanase d'Alexandrie, in OCP 62 (1996) 185-195; D. GonNET, L'utilisation christologique de l'Epitre aux Hébreux dans les Orationes Contra Arianos d'Athanase d'Alexandrie, in Studia Patristica 32 (1997) 19-24.

5. At the end of the article we provide a list of all the passages where Athanasius borrows from the Book of Wisdom. 
is the fact that so far no research has been done into Athanasius' use of Wisdom Literature. Secondly the Book of Wisdom gradually developed during the patristic period into an important theological source. Some passages played a prominent role in the works of the Alexandrian authors before Athanasius. By the fourth century the book, despite the existing doubts on its canonicity, had become a locus theologicus of considerable importance. The book increased in importance in the theology of authors such as Gregory of Nyssa and Augustine. As examples of much used proof texts can be mentioned the following: Wisd 1,7 for the development of a theology of the Holy Spirit; Wisd 2,23-24 about immortality and Wisd 7,25-26 contributed immensely to the reflection about the relationship between the Father and the Son ${ }^{6}$. An overview of Athanasius' use of Wisdom may contribute to the assessment of his place in this development. A final, more practical reason was that there are relatively few clear-cut ${ }^{7}$ cases where Athanasius uses Wisdom, which makes it possible to present them into some detail.

On the basis of a presentation of the passages where Athanasius borrows from the Book of Wisdom, this article aims to address two issues. The first issue concerns the famous passage in his Festal Letter of $367^{8}$,

6. For a survey of the use of Wisdom in patristic literature see: C. LARCHER, Études sur le Livre de la Sagesse (Études bibliques), Paris, 1969, pp. 36-54; M. GILBERT, art. Sagesse de Salomon, in DSpir 14 (1988), col. 57-72, 66-67; S. LEANZA, art. Wisdom Books, in A. DI Berardino (ed.), Encyclopedia of the Early Church, vol. II, Cambridge, 1992, pp. 878-881, 881. For the Alexandrian authors see also W. VöLKER, Die Verwertung der Weisheits - Literatur bei den christlichen Alexandriner, in ZKG 64 (1952-53) 1-32; R.M. GRANT, The Book of Wisdom at Alexandria. Reflections on the History of the Canon and Theology, in ID., After the New Testament, Philadelphia, 1967, pp. 70-82 (Early Use, Clement, Origen, Dionysius, Theognostus and other examples); A.H.B. LogAn, Origen and Alexandrian Wisdom Christology, in R. HANSON - H. CROUZEL (eds.), Origeniana Tertia. The Third International Colloquium for Origen Studies (University of Manchester September $\left.7^{\text {th }}-11^{\text {th }}, 1981\right)$, Roma, 1985, pp. 123-129. Both Grant and Logan focus on Wisd 7,25-26. See also the article by M. DEMURA, Origen on Sophia in Contra Celsum: The Double Understanding of the Wisdom of Solomon 7:27, in R.J. DALY (ed.), Origeniana Quinta, Papers of the $5^{\text {th }}$ International Origen Congress, Boston College, 14-18 August 1989 (BETL, 105), Leuven, 1992, pp. 174-178. For Augustine, see A.-M. LA BonNARDIÈRE, Biblia Augustiniana. Le Livre de la Sagesse (Études augustiniennes), Paris, 1970; for Gregory of Nyssa, see M. CANEVET, Grégoire de Nysse et l'herméneutique biblique. Étude des rapports entre le langage et la connaissance de Dieu (Études augustiniennes), Paris, 1983, pp. 130-132; Biblia Patristica. V. Basile de Césarée, ..., Paris, 1991, pp. 249-251.

7. We do not include in our presentation two extremely vague allusions: one to Wisd 4,15 in Vita Antonii, 58.4 (SC, 400, pp. 290-291) and one to Wisd 15,3 in De Sententia Dionysii, 10.5 (H.G. OpITZ, Athanasius' Werke. II. Die Apologien, Berlin - Leipzig, 1939, p. 54). We neither include Athanasius' quotations from other authors. So we omit three quotations from the work of Dionysius of Alexandria which contain references to Wisd 7,25-26: cf. De Sententia Dionysii, 15.2; 15.5; 23.2 (H.G. OpITZ, Apologien, pp. 57; 63).

8. A large part of the Letter has been preserved in Greek in collections of canon law. The most recent edition of the Greek text is by P.P. JoAnnou, Discipline générale antique (IVe-IX s.). II. Les canons des Pères Grecs (Fonti, IX/2), Grottaferata, 1963, pp. 71-80. An 
where he distinguishes between the books he calls "canonical" ( $\beta 1 \beta \lambda$ í $\alpha$

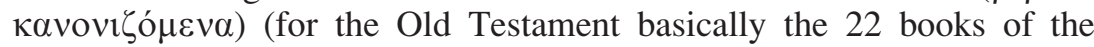
Jewish canon) and the books to be read to the catechumens. In this second category, clearly separate from the "canonical books", he places Wisdom, Wisdom of Jesus Sirach, Tobit, Judith and Esther; the Shepherd of Hermas and the Didache. A.C. Sundberg and C. Larcher noted that Athanasius uses these books in the same way as those he calls "canonical" But since their primary interest was in the history of the canon, they did not go into this question in depth. We will give their argument a more solid foundation? .

The second aim of this article is to highlight the variety in Athanasius' use of Scripture. This variety shows itself in two ways. It is most visibly reflected in his quoting or alluding to a great number of different pas$\operatorname{sages}^{10}$. Athanasius surely has his favourites, passages he quotes and repeats endlessly. Among such passages are: John 10,30 ("The Father and I are one"); 14,6 ("I am the Way and the Truth and the Life. No one comes to the Father but by Me"); and 14,9 ("He that has seen Me, has seen the Father"). Besides these, there are literally hundreds of passages used only a few times, or even only once. A presentation of the passages where he uses one particular part or book of the Bible helps to grasp something of this variety.

He also displays a variety of purpose in his Scriptural borrowings. His primary purpose is to support theological argumentation. An analysis of his use of Wisdom in his theological writings shows that passages from Wisdom are adduced to support a wide variety of theological ideas. But Athanasius also uses Scripture for other purposes. Scriptural quotations and allusions play a vital role in his portrayal of the ascetic ideal in the

extant Coptic translation contains large portions of the text: cf. text and French translation L.-T. LEFORT (ed.), S. Athanase. Lettres festales et pastorales en Copte (CSCO, 150-151), Leuven, 1955, pp. 58-62 (Coptic text), pp. 31-41 (French translation). R.-G. CoQuIN published an additional fragment in Les lettres festales d'Athanase (CPG 2102). Un nouveau complément: Le manuscrit IFAO, Copte 25, in OLP 15 (1984) 133-158. An English translation of a composite text can be found in D. BRAKKE, Athanasius and the Politics of Asceticism (Oxford Early Christian Studies), Oxford, 1995, pp. 326-332. For a recent study see his Canon Formation and Social Conflict in Fourth Century Egypt: Athanasius of Alexandria's Thirty-Ninth Festal Letter, in HTR 87 (1994) 395-420.

9. A.C. SundBERG, The Old Testament of the Early Church (Harvard Theological Studies, 20), Cambridge MA, 1964, pp. 139-141; C. LARCHER, Études (n. 6), pp. 48-49. Already J. Ruwet, Le canon Alexandrin des Ecritures. Saint Athanase, in Biblica 33 (1952) 1-29 came to this conclusion, but on the basis of few texts (p. 9 with note 5): Wisd $14,12-21 ; 1,5 ; 1,7 ; 12,1$. Yet it seems not to have seeped through into common knowledge. So the introduction to the Dutch translation of Wisd in De Bijbel. Uit de grondtekst vertaald. Willibrordvertaling, geheel herziene uitgave, 's Hertogenbosch, 1995, states: "Origenes en Athanasius in het Oosten, en Hieronymus in het Westen beschouwden het wel als een stichtelijk maar niet als een geïnspireerd boek” (p. 920).

10. The Scriptural index in G. MüLler, Lexicon Athanasianum, Berlin, 1952, col. 1635-1664, provides the necessary material for a quick assessment of this kind of variety. 
Vita Antonii and in the demonology that is quite strongly present in this work $^{11}$. Furthermore, Scriptural borrowings are an important part of his apologetical technique ${ }^{12}$. Finally, we should take into account that Athanasius, deeply imbued in the Scriptures, used many biblical images or expressions without a clear purpose; they were, so to speak, part of his vocabulary.

\section{Wisd 14, 12-21: Against Pagan Idolatry in Contra Gentes}

The Contra Gentes and its pendant De Incarnatione Verbi form a double work ${ }^{13}$. This apologetical treatise is Athanasius' first long dogmatic writing ${ }^{14}$. In the Contra Gentes he expounds the Christian faith's objection to heathenism. Pagans ridicule the Cross and laugh at it. They do not understand that, because $\mathrm{He}$ who ascended the Cross was the Word of God, knowledge of God is possible for everyone. But the Cross is not the only way to know God: He can be known through His creation and through the Scriptures. This is the basic message of the Contra Gentes stated positively. Stated negatively, Athanasius refutes pagan idolatry because it corrupts the human soul. This soul was originally created to partake of the divine nature. Through the grace it received from the divine Logos, the uncorrupted soul lived in fellowship with the image of God,

11. Cf. e.g., M.G. MARA, Bibbia e storia nel fenomeno monastico: la vita Antonii, in E. Romero-Pose, et. al. (ed.), Plèroma. Salus carnis. Homenaje a Antonio Orbe SJ, Santiago, 1990, pp. 561-573; A. Tonini, Lettura spirituale della Scrittura nella "Vita Antonii" di Atanasio, in Claretianum 32 (1992) 321-391; G.J.M. BARTELInK, (ed.), Athanase d'Alexandrie. Vie d'Antoine (SC, 400), Paris, 1994, pp. 48-54.

12. With this term we refer to a conglomerate of various means to denounce or ridicule those he wants his readers to perceive as his enemies. These include: a varied and extensive polemical vocabulary, the omission or distortion of historical facts, rhetorical techniques such as invented dialogues, irony and sarcasm, the undifferentiated juxtaposition of very diverse groups (Arians, Eusebians, Melitians), the association of his enemies with Jews or other biblical characters taken to be ignominious, applying a Scriptural quotation to his enemies. For quotations from Wisdom used in this way, see: Wisd $1,11 \mathrm{~d}$ in the Apologia Secunda contra Arianos 3.4 (H.G. OpITZ, Apologien [n. 7], p. 89) and in the Apologia ad Constantium 5,20 (SC, 56bis, p. 98); Wisd 2,21 in Historia Arianorum 71.3 (H.G. OpITZ, Apologien [n. 7], p. 222). About his polemical terminology see D. SCHMITZ, Schimpfwörter in Athanasius' Reden gegen die Arianer, in M. Wisseman (ed.), Roma renascens. Beiträge zur Spätantike und Rezeptionsgeschichte. FS Ilona Opelt, Frankfurt, 1988, pp. 308-321. For some general remarks about Athanasius' apologetical technique in his historical-polemical writings, see T.D. BARnes, Athanasius and Constantius. Theology and Politics in the Constantinian Empire, Cambridge MA - London, 1993, esp. pp. 121135 .

13. On the interrelationship of both writings, see E.P. MEIJERING, Struktur und Zusammenhang des apologetischen Werkes des Athanasius, in Vigiliae Christianae 45 (1991) 313-326.

14. His very first work that can be styled "dogmatic" was the letter Henos Somatos, which he wrote in the name of his bishop Alexander. Cf. C. STEAD, Athanasius' Earliest Written Work, in JTS 39 (1988) 76-91. 
God's Logos, according to whose image man was created. But sensible, corporeal, physical lust corrupted humanity. So gradually the soul descended from its original pure level to baser and evil things. Athanasius explicitly insists that humanity chose to descend to this evil situation: all explanations attributing or relating the origins of it to God are explicitly rejected (1-7). It is against this background that his long refutation of idolatry must be seen. The sensible world did more than entice humanity away from its original pure state, it permitted humanity to create, out of nature and reality, new gods as replacements for the one, only true God of Jesus Christ. Seen in this perspective, idolatry is for Athanasius the summum of neglecting God. He refutes it at length, disposing first of idolatry in se (8-15) and then widening his scope to pagan polytheism in general (16-30). These first thirty chapters of Contra Gentes contain citations from Wisdom.

To support his ideas that the soul fell because it became corrupted by lust, Athanasius considered Wisd 14,12 the perfect Scriptural proof text:

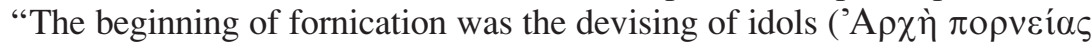

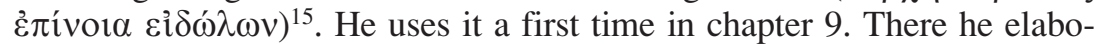
rates on the idea that, once human minds had been degraded and distracted and turned away from God, they venerated the sun, the moon etc. instead of paying honour to God. They gave to natural elements - stone, wood, animals - the honour due to God. They even venerated the feelings which caused their debasement: pleasure and desire. They deified their rulers, the sons of their rulers and even their emperor's favourites. Hadrian's boyfriend, Antinous, for whom Hadrian himself decreed that a cult should be organized, is the classic example. Athanasius continues ${ }^{16}$ :

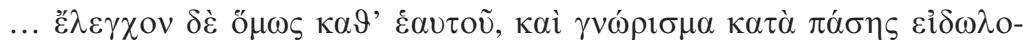

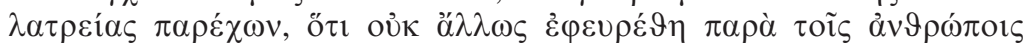

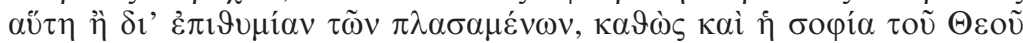

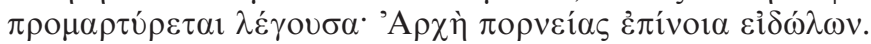

It should be noted that the formula Athanasius uses to introduce the quo-

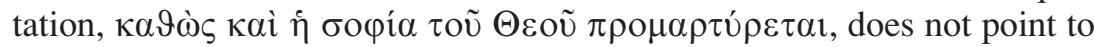
an inferior status of the Book of Wisdom vis à vis the "canonical books"17. To introduce a quotation Athanasius has most of the time a

15. We quote the text of Wisdom as Athanasius gives it, not that of the LXX, without a discussion of the differences as they are only minor and of no importance for our topic.

16. "Yet he (Hadrian) brought condemnation on himself and provided a proof that all idolatry was invented by men for no other reason than the passion of those who contrived it, just as the Wisdom of God previously indicated, saying The beginning of fornication was the devising of idols". Greek text and English translation by R.W. THOMSON, (ed.), Athanasius. Contra Gentes and De Incarnatione (Oxford Early Christian Studies), Oxford, 1971, pp. 26-27.

17. In what follows "canonical books" stands for "books Athanasius qualified as

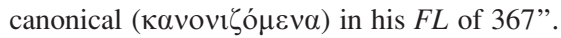




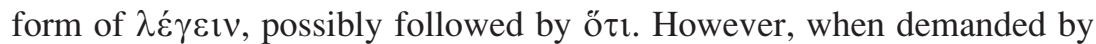
the structure of the sentence, a main verb together with a participium of $\lambda \dot{\varepsilon} \gamma \varepsilon \omega v$ is certainly no exception. This is here the case with regard to a quotation from the Book of Wisdom but the examples given below show that this construction occurs also to introduce quotations from "canonical books" 18 .

Athanasius goes on to denounce the ancient Greek custom of worshipping human beings as gods. This leads him to cite Wisd 14,12 again, but this time with the following verses, up to v. 21. This quotation from Wisd $14,12-21$ is one of the longest in Athanasius' oeuvre. It is interesting to

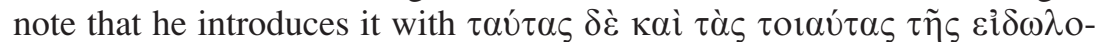

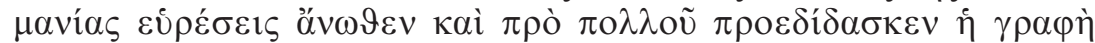
$\lambda \dot{\varepsilon} \gamma o v \sigma \alpha^{19}$. Since he is explicitly introducing it as "Scripture" ${ }^{20}$, this passage is a clear example of how Athanasius in practice valued Wisdom as highly as the "canonical books". It is also interesting in this respect that this quotation is not supported by other quotations from the "canonical books". To Athanasius the weight of this long quotation from Wisdom was sufficient to make his point.

A rather short citation of Wisd 14,21b ("They confer on stocks and stones the name that none may share") is found in Contra Gentes 17, where Athanasius is still refuting pagan idolatry. Athanasius hints at the many disgraceful acts of the gods in pagan mythological tales. He argues that the pagans conferred upon these people a superhuman, divine status because they were unable to find excuses for their behaviour. Here Athanasius uses one of his many rhetorical techniques: he refutes the wrong reasoning he himself put in the mouth of his opponents. The pagans' divinizing of mortal men in order to excuse the disgrace of their acts proves according to Athanasius that they were not at all worthy of a divine status ${ }^{21}$ :

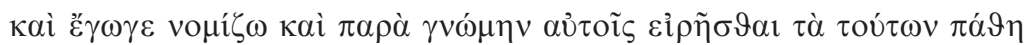

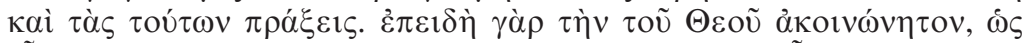

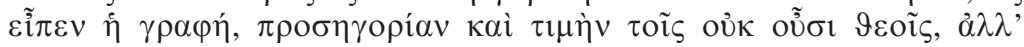

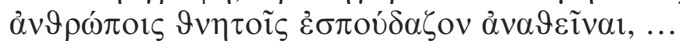

18. Cf. G. MüLleR, Lexicon (n. 10), col. 810-817. Some examples of a main verb +

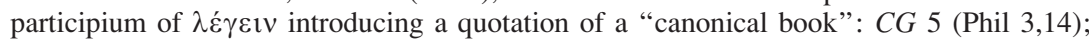
CG 8 (Prov 18,3); CG 46 (Gen 1,26); DIV 18 (Jn 10,38); DIV 35 (Deut 28,66); Epistula Encyclica, 1 (Mt 28,19); Apologia Secunda contra Arianos, 82 (Acts 24,19).

19. CG 11. ET: "Long ago Scripture taught about these and similar inventions of idolatry, saying:...." (R.W. Thomson, Athanasius [n. 16], pp. 30-31.

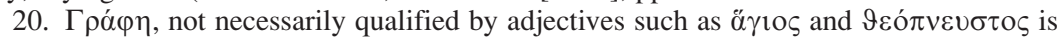
Athanasius' common indication for Holy Scripture. Cf. G. MüLLER, Lexicon (n. 10), col. 256-258.

21. $C G$ 17. "I personally think that they (sc. the pagans) spoke of their passions and actions against their will. For since they were eager to ascribe the incommunicable name, as Scripture says, of God and the honour due to him to being who are not gods but mortal men" (R.W. Thomson, Athanasius [n. 16], pp. 48-49). 


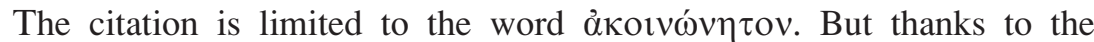
explicit introductory formula ( $\dot{\varsigma} \varepsilon \tilde{\tilde{i}} \pi \varepsilon v \dot{\eta} \gamma \rho \alpha \varphi \eta ́)$ and to the presence of the two earlier mentioned quotations from Wisd 14 in chapters belonging to the same context, we can be fairly sure that Athanasius has Wisd $14,21 \mathrm{~b}$ in mind. This is thus the second example of a passage from Wisdom explicitly put forth as belonging to Scripture. As in the first case, there is no other citation from a "canonical book" present in the vicinity to corroborate the testimony of the text from Wisdom.

\section{Incorruptibility and Immortality in De Incarnatione Verbi 4-5}

Athanasius' theology and his defence of the ónoovi $\sigma$ to $\varsigma$ is strongly coloured by a soteriological concern: by His Incarnation the Logos leads mankind back to its original situation of felicity that it enjoyed before the fall. Original sin is thus inserted in the soteriological scheme of the divine economy and is made subordinate to God's pronoia. Since the fall is foreseen and is considered an integrating part of the divine economy, it loses something of its sharpness. We will now discuss some passages from the first chapters of the De Incarnatione Verbi in which Athanasius deals with the fall and where he has woven borrowings from Wisdom into his argument ${ }^{22}$.

At the start of this work, Athanasius briefly summarizes some of the thoughts he evoked in Contra Gentes. He reminds his readers how Christians are to understand the creation of the world. Rejecting the idea of certain pagan philosophers (e.g., the Epicureans and Plato), he asserts that for the Christian the only reasonable thing to believe is that God made everything out of nothing through His Word, our Lord Jesus Christ. God did show a special predilection for mankind: He made man as His image, as it were, as a shadow of His own Word, with the capacity to remain forever in felicity. Mankind, however, chose to transgress God's law and pursue the path of wickedness ${ }^{23}$.

At this point Athanasius enters the main topic of the De Incarnatione Verbi: Christ's incarnation is an act performed for our salvation. Mankind needed this salvation because it had chosen to transgress the law of God. Remaining in the contemplation of the eternal God, the state in which man was created, would have led to immortality, effected by the growing similarity to the object of contemplation. But the opposite is also true: choosing wickedness leads to destruction. Consequently humanity lost

22. For general accounts of Athanasius' ideas on original sin, see J. Gross, Geschichte des Erbsündendogmas. I. Entstehungsgeschichte der Erbündendogmas. Von der Bibel bis Augustin, München - Basel, 1960, pp. 125-133; L. SCHEFFCZYK, Urstand, Fall und Erbsünde. Von der Schrift bis Augustin (Handbuch der Dogmengeschichte, II 3a), Freiburg Basel - Wien, 1981, pp. 124-130.

23. DIV 1-4 (R.W. Thomson, Athanasius [n. 16], pp. 134-143). 
eternal life. Death reigned. Transgression resulted in what was natural for something created from nothing: banishment from eternal life. This means that after death, mankind remains in death and corruption. Athanasius explains further ${ }^{24}$ :

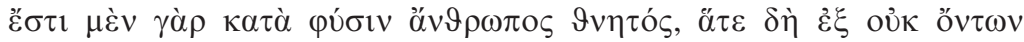

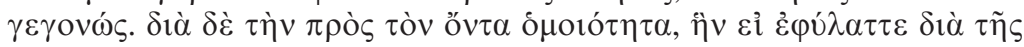

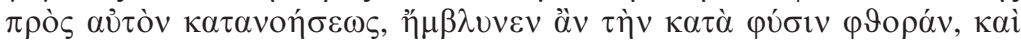

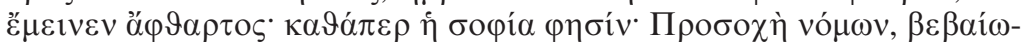

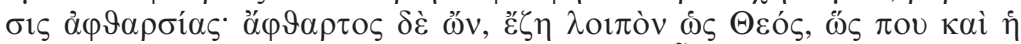

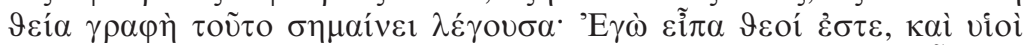

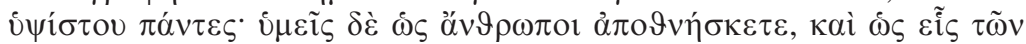
$\dot{\alpha} \rho \chi \delta ́ v \tau \omega v \pi i \pi \tau \varepsilon \tau \varepsilon$.

Here the citation from Wisd 6,18 ("The keeping of the law is the assurance of incorruptibility") supports a theological argumentation. Yet one gets the feeling that this affirmation has been tacked on, since the argument had already been concluded. It has a post factum character. This has to do with Athanasius' principle of the skopos, one of the basic presuppositions of his theology, which functions as a hermeneutical key for the interpretation of the Scriptures. Yes, Athanasius gained his theological insights not so much from a careful reading of the Scriptures as we, seeing from today's practice would expect. It is rather his skopos (viz. the double nature of the Logos) that dictates what results his interpretation of the Bible will yield. So his theology took place in a constant interplay between this theological presupposition and those elements of Scripture that could provide support for $\mathrm{it}^{25}$. However this should not make us forget that, though the citation does not add anything substantial to

24. DIV 4. "For man is by nature mortal in that he was created from nothing. But because of his likeness to him who exists, if he had kept this through contemplating God, he would have blunted his natural corruption and would have remained incorruptible, as the Book of Wisdom says: "the keeping of the law is the assurance of incorruptibility"(Wisd 6,18b). But being incorruptible he would thenceforth have lived like God, as also somewhere the Divine Scripture declares, saying:"I said that you are gods and all sons of the Highest: but you die like men and fall like one of the princes' (Ps. 81,6-7)" (R.W. Thomson, Athanasius [n. 16], pp. 144-145).

25. The scope of this article does not permit to treat the important question of this hermeneutical approach in depth. We refer the reader to the following literature: T.E. PoLLARD, The Exegesis of Scripture and the Arian Controversy, in BJRL 41 (1958-59) $414-$ 429; J. IBAÑEZ, Naturaleza de la Eusebeia en S. Atanasio, in Scripta Theologica 3 (1971) 31-73; H.J. SiEBen, Herméneutique de l'exégèse dogmatique d'Athanase, in C. KANNENGIESSER (ed.), Politique et théologie (n. 4), pp. 195-215; W. SCHNEEMELCHER, Der Schriftgebrauch in den "Apologien" des Athanasius, in M. BRECHT, (ed.), Text-WortGlaube. FS Kurt Aland (Arbeiten zur Kirchengeschichte, 50), Berlin - New York, 1980, pp. 209-219, 209; J.D. ERNEST, Athanasius of Alexandria: the Scope of Scripture in Polemical and Pastoral Context, in Vigiliae Christianae 47 (1993) 341-363; T.F. ToRRANCE, The Hermeneutics of Athanasius, in Id., Divine Meaning. Studies in Patristic Hermeneutics, Edinburgh, 1995, pp. 229-288 (originally published in 1970-1971). 
Athanasius' argument, the authority ascribed to Scriptural texts was lending it extra support.

Athanasius only cites the second part of the verse. The first part ("Her love means the observation of her laws") could have strengthened the power of this proof text. Maybe he omitted it because of the explicit female possessive pronoun attached to "laws" that made the application of this text about Wisdom to Christ somewhat difficult ${ }^{26}$. Further, it

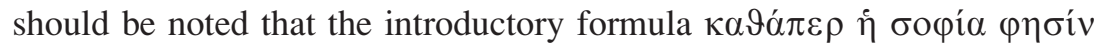
does not allow any conclusions about the canonicity of Wisdom. It merely indicates which book of Scripture is cited, in contrast to the ensuing quotation of Ps 81,6-7, which is explicitly introduced as a citation from Scripture. At first sight this opposition argues against an equal status for the Book of Wisdom vis à vis the "canonical books". However Athanasius also often introduces a quotation from a "canonical book" by indicating its provenance ${ }^{27}$. Moreover, the quotation from Wisdom is here accompanied by one from a "canonical book".

So far, the reader may have the impression that Athanasius blames only mankind for the transgression of the law. But then he repeats that God intended us to live a divine life. It was the Devil's advice that led mankind astray from the eternal and that was the cause of corruption and death. But let there be no misunderstandings: mankind was created in the image of God, but on the natural level remained corruptible. By the grace of mankind's participation in the Word corruptible nature was, as it were, superseded and granting humanity the opportunity to escape the consequences of nature. A precondition for remaining in this state was remaining virtuous. Athanasius found a strong proof text in Wisd 2,23-24 28 :

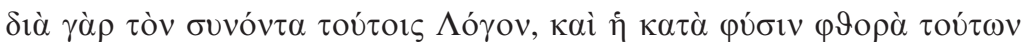

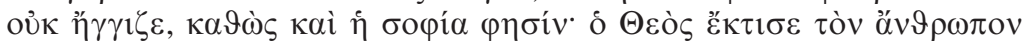

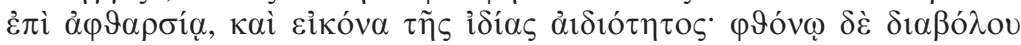

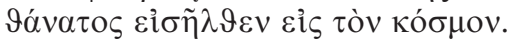

26. Note that Athanasius' use of Wisd 6,18 in this context was very innovative. Before him only Clement had used it in developing his concept of love and its relation to and difference from knowledge. Cf. Clement, Stromata VI, 121.1 (GCS, 52 ${ }^{3}$, p. 492); Paedagogus II, $7.1\left(G C S, 12^{2}\right.$, p. 157).

27. The Psalms are a case in point: $C A$ I,12 (Ps 89, 17); $C A$ I, 41 (Ps 89, 17.18); Epistula ad episcopos Aegypti et Libyae, 17 (Ps 52,1.2; Apologia de fuga sua, 24 (Ps 136,1ss) and of course the Epistula ad Marcellinum, passim. Cf. G. MüLler, Lexicon (n. 10), col. 1595-1596. Further examples chosen at random: $C A$ I, 12 (Heb 1,3); $C A$ I, 40 (Phil 2,511); $C A$ II, 4 (Isa 38,19 and 2 Kings 20,18); CA II, 32 (Jn 1,1 and LK 1,2); Apologia de fuga sua, 14 (Eccl 7,17); Historia Arianorum, 77 (Dan 9,27).

28. DIV 5. "For on account of the Word who was in them, even natural corruption would not have touched them, as the book of Wisdom says: 'God created men for incorruption, and made him the image of his own eternity; but by the envy of the Devil death entered the world"” (R.W. Thomson, Athanasius [n. 16], pp. 144-145). 
This is a very fitting Scriptural proof in support of what he is saying. The text, which mentions mankind's immunity to natural corruption, the image of God's eternity and the Devil's envy is, as it were, tailor-made

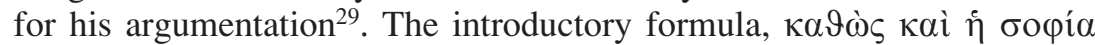

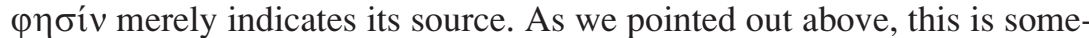
thing he also often does when introducing borrowings from "canonical books".

\section{Wisd 13,5: Traces of the Creator in the Visible World}

As we have seen, the first part of Contra Gentes is devoted to a refutation of pagan idolatry. From chapter 30 onwards, Athanasius develops a positive counterpart to the preceding chapters by expounding on how the soul and the intellect residing in it can acquire knowledge of God. While it is impossible for the soul to cleanse itself from the stain of lust and evil, which cleansing would make it again able to partake of the divine nature, this knowledge about God can also be derived from creation. For God's creation, through his Logos, of everything out of nothing is so to speak His masterpiece (30-34). The chapters 35-44 are devoted to the development of a creation theology. God reveals himself in the order and harmony clearly present in creation ${ }^{30}$. The order we see in the universe, despite the very diverse and opposing elements that comprise it, requires us to suppose a Creator. For the same reason there can be only one Creator: otherwise there would not be such a degree of harmony in creation $^{31}$. And who is this Creator? Of course, Athanasius says, this can be none other than "the all-holy Father of Christ, beyond all created being, who as supreme steersman, through his own Wisdom and his own Word, our Lord and Saviour Christ, guides and orders the universe for our salvation, and acts as seems best to him"32. Then he goes on to elucidate the

29. Other authors also used this influential text quite often: ORIGEN, Homiliae in Ieremiam 2.1 (SC, 232, p. 238); Commentarium in Ioannem XX, 236; XXXII, 22 (SC, 290, p. 274; SC, 385, p. 196); Commentarium in Romanos 5.1; 6.6 (Fontes Christiani 2/3, p. 64-65; 228-229); MEthodius of Olympus, De resurrectione I, 36.2; I, 37.3; I, 50.4; II, 24.4 (GCS, 27, pp. 276; 278; 304; 380); De libero arbitrio (Patrologia Orientalis, XX, p. $803 ; 805 ; 809 ; 815)$; EusEBIUs, Praeparatio evangelica VII, 10.15; XIII, 3.38 (GCS, 43.1, p. 382; GCS, 43.2, p. 175).

30. CG 35: "God, who is good and loves men and who cares for the souls he has made, since he is by nature invisible and incomprehensible, being above all created being, and therefore the human race would fail to attain knowledge of him in that they were made from nothing while he was uncreated - for this reason God so ordered creation through his Word that although he is invisible by nature, yet he might be known to men from his works" (R.W. Thomson, Athanasius [n. 16], pp. 94-95).

31. CG 39: "If creation is one, and the world is one, and its order is one, then we must consider that it has one Lord, its king and creator" (R.W. Thomson, Athanasius [n. 16], pp. 108-109).

32. CG 40 (R.W. Thomson, Athanasius [n. 16], pp. 110-111). 
Logos' intermediary role. It is the Logos who produced order and harmony among all things, who caused the heavens to revolve and the earth to suspend. When this first stage of the creation was passed, and the harmony established, the Logos did not abandon the earth and people. God knows the volatile nature of created things, human beings included. $\mathrm{He}$ continues to guide His creation, so that it might abide always in security (40-44). At the end of this part of Contra Gentes, at the apex of his argument, Athanasius resumes his initial thought that we can know God the Creator through His creation. He illustrates this with a quotation from Wisd 13,5. The quotation is without introductory formula woven into the text. Athanasius concludes his description of the activity of the Logos as follows ${ }^{33}$ :

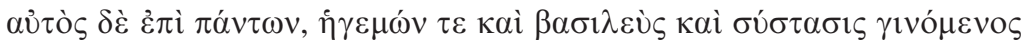

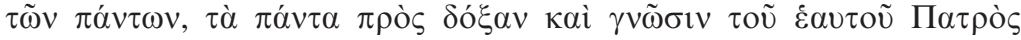

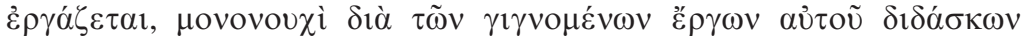

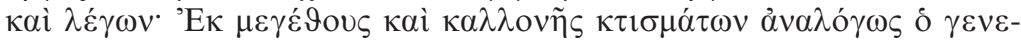

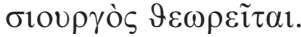

The quotation of Wisd 13,5 is here introduced by two participia

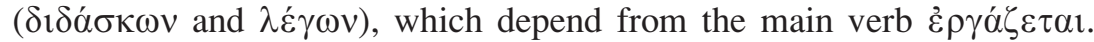
Above we already noted that this is a not unusual construction for Athanasius to insert quotations from "canonical books" into his writings ${ }^{34}$. So once more we conclude that there is no difference here with the "canonical books".

Athanasius also uses Wisd 13,5 in the second book of Contra Arianos, his most important dogmatic work ${ }^{35}$. This second book probably dates from about $340^{36}$. Athanasius was in Rome at that time. A Council in

33. CG 44 (R.W. Thomson, Athanasius [n. 16], pp. 122-123): "And he in all things, being leader and king and support of all, works everything gor the glory and knowledge of his Father, teaching through the works he accomplishes that: 'From the greatness and beauty of the creatures by analogy their creator is known"'. We have changed the interpunction before the quotation. Thomson's edition has there a full stop but since a main verb + participium of $\lambda \varepsilon \dot{\gamma} \varepsilon \downarrow v$ is a normal way to introduce a quotation (see n. 18), a colon seems more logical and more in line with his translation. Both $P G$ 25, col. 87-88 and L. LeOne (ed.), Sancti Athanasii archiepiscopi Alexandriae Contra Gentes. Introduzione testo critico - traduzione (Collana di studi greci, 43), Naples, 1965, p. 87 print a colon.

34. See p. 354 with note 18 .

35. A telling indication that at least some later Christian generations considered Contra Arianos in this way, is that in later iconography Athanasius is depicted holding a codex with the text of Contra Arianos. Cf. J. Myslivec, art. Athanasius von Alexandrien, in E. KirschBAuM - W. Braunfels (eds.), Lexikon der christlichen Ikonographie, vol. 5, Roma - Freiburg - Basel - Wien, 1973, col. 269-271.

36. The date is disputed. C. KANNENGIESSER, Athanase d'Alexandrie, évêque et écrivain. Une lecture des traités Contre les Ariens (Théologie historique, 70), Paris, 1983, has shown that the three books could not have been written at the same time, regardless of whether one agrees with his claim that the third book is inauthentic. A date around 340 seems best on following grounds: (1) On the basis of CA I,10 we know that the work must 
Antioch had deposed him in 338 and Constantius, who sympathised with Athanasius' enemies, effected his expulsion aided by the military force of Philagrius, the praefectus Aegypti. Athanasius left Egypt for Rome in April 339. He realised that, to find enduring support in the West and to stand a chance to return to Alexandria as its bishop, he had to convince his allies that by lending him their support they were supporting the cause of orthodoxy against the Arian heresy. Contra Arianos has to be seen in this light ${ }^{37}$. The work's central question is: which theology, the Arians' or Athanasius', presents Jesus Christ truly as God and as Son of the Father? The Arian doctrine has to be rejected, since it holds that the three persons of the Trinity are completely dissimilar and by consequence, that the Son is unlike the Father, even foreign to Him with respect to essence. Athanasius defends the opposite: the Son is like the Father, in all things, essence included. The bulk of the treatise is a rebuttal of the proof texts which the Arians used showing that these texts, when correctly interpreted, support not the Arians' heretical but Athanasius' orthodox beliefs. The lion's share of the second book is devoted to a thorough commentary on Prov 8,22: "The Lord has created me at the beginning of his ways for His works" (18b72). The chapter which interests us, Contra Arianos II, 32, is situated in the first subsection of this part (18b-43), which can best be considered a long introduction to the exegesis stricto sensu of Prov 8,22, which follows from 44 onwards.

Having expounded the uncreated nature of the Son, rejecting the idea the Son is a $\pi$ oí $\mu \alpha(18 \mathrm{~b}-23)$ and having reflected on the relationship between the Father and the Son (24-31), Athanasius starts in chapter 32 with a new line of thought. In chapters 32-36 he develops some thoughts on the language of Scripture, which is full of images. Only an orthodox reading and interpretation of these passages reveals something of the divine mystery. A prerequisite is an exegesis in line with what lives in the ecclesial community. And this is identical with the skopos of Scripture: the double nature of the Logos. On that basis Athanasius looks to the Arian catchwords and exegesis. He concludes that the Arians' interpretation of Scripture is completely wrong and therefore that they have understood nothing of God and his creative

be dated somewhere during Constantius' reign (337-361); (2) A date in the latter part of this period can be rejected, though not with $100 \%$ certainty, on theological grounds: the

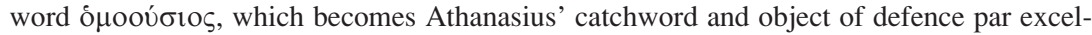
lence during the $350 \mathrm{~s}$, is seldom used; on the other hand Athanasius uses terms such as

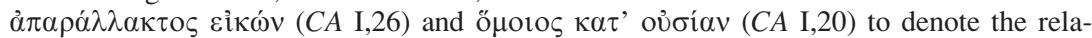
tionship between the Father and the Son. These terms are typical for two creedal formulas from 341, issued by his theological opponents (council of Antioch and Macrostich), which makes it unlikely that Athanasius would use them, implying his agreement after they were issued. Cf. R.A. Riall, Athanasius Bishop of Alexandria: The Politics of Spirituality, unpublished dissertation, Univ. of Cincinnati, 1987, pp. 400-403.

37. T.D. BARnes, Athanasius and Constantius (n. 12), pp. 47-56. 
and salvific act through His $\operatorname{Logos}^{38}$. This is the context of the following passage ${ }^{39}$ :

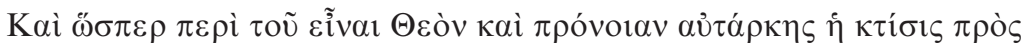

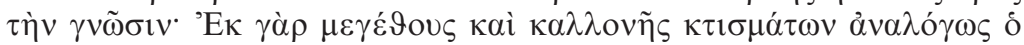

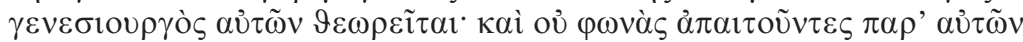

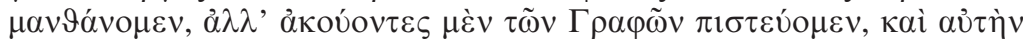

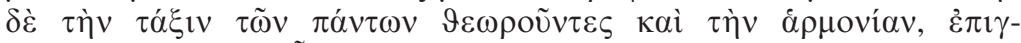

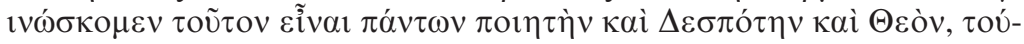

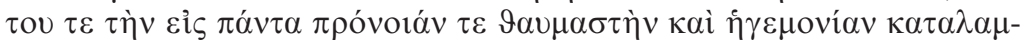

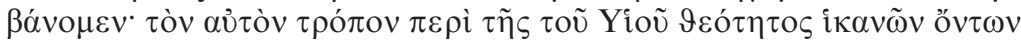

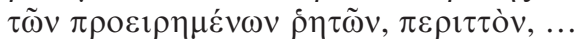

Athanasius uses here in a summarized version the argumentation of Contra Gentes 30-44. Here, however, it fits in a somewhat different context. In the Contra Gentes 44, Athanasius used Wisd 13,5 to show that, although mankind lost its original blessed state of participating via the Logos in knowing God, it is to a certain degree still possible to know God via His creation. In Contra Arianos II,32 the idea of knowing God through His creation is not important in itself, but functions as one half of a parallelism. Just as we know about God through His creation and the Scriptures, so can we know about the Son's divine essence. What the Scriptures reveal about the relationship between the Father and the Son, however dim and poor it may be, is sufficient to demonstrate that the Logos is eternal, not a created being, and that he is not foreign to the essence of the Father.

\section{4. "Sovereignty over the Creatures" (Wisd 9,2) and "He Created" in Contra Arianos II, 45}

The passage we now are concerned with is at the beginning of the

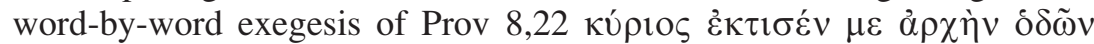

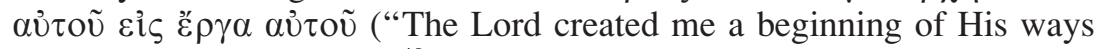
for His works") $(\mathrm{II}, 44-52)^{40}$. Athanasius points to the figurative character

38. For this structure of Contra Arianos II, see C. KANNENGIESSER, Évêque et écrivain (n. 36), pp. 68-93.

39. CA II, 32: "And as the creation contains abundant matter for the knowledge of the being of a God and a Providence ("For by the greatness and beauty of creatures proportionably the Maker of them is seen") (Wisd 13,5) and we learn from them without asking for voices, but hearing the Scriptures we believe, and surveying the very order and the harmony of all things, we acknowledge that he is Maker and Lord and God of all, and apprehend His marvellous Providence and governance over all things; so in like manner about the Son's Godhead, what has been above said is sufficient, and it becomes superfluous"; cf. $P G$ 26, col. 216; ET: A. Robertson (ed.), Athanasius (Nicene and Postnicene Fathers of the Church, second series, vol. 4), pp. 365-366.

40. For the structure and content of this part of the Contra Arianos, see C. KANNENGIESSER, Évêque et écrivain (n. 36), pp. 83-92. 
of the book of Proverbs, meaning that it is not to be understood literally, but that the latent sense must be uncovered. With this principle as a key, Athanasius begins his word-by-word exegesis. He starts with a thorough discussion on the meaning of $\dot{\varepsilon} \kappa \tau 1 \sigma \varepsilon \dot{\varepsilon} v$ ("He created"). According to Athanasius, it means the same as $\dot{\varepsilon} \gamma \dot{\varepsilon} v v \eta \sigma \varepsilon v$ (He begat) and therefore gives no support to the Arian interpretation of Prov 8,22, which claims that the passage proves that Christ was a created being $(\kappa \tau i \sigma \mu \alpha)$. When Prov 8,22 says of Christ that He is created, it does not necessarily mean that $\mathrm{He}$ is also a created being on the ontological level. The text does not say "I am a creature", or something unequivocal like that. The text has to be interpreted as saying something about His human form of appearance among us, not about his essence. Athanasius then argues for this difference in interpretation on a Scriptural basis. First he quotes some passages to show that being called creatures and being created, belong to things which have a created essence by nature. But he cites other passages to

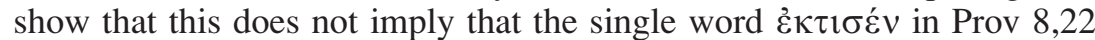
necessarily points to a created essence and mode of generation ${ }^{41}$. Working to the conclusion of this part, Athanasius writes in II, $47^{42}$ :

For the Lord, knowing His own essence to be the Only-begotten Wisdom and Offspring of the Father, and being different from things originate and natural creatures, says in love to men: "The Lord created me a beginning of His ways", as if to say, "My Father prepared for Me a body, and created Me for men on behalf of their salvation".

In the same series of texts intended to prove that being called creatures and being created are characteristic of things which have by nature a cre-

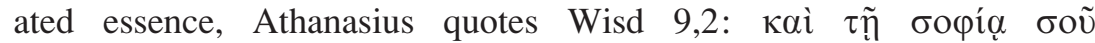

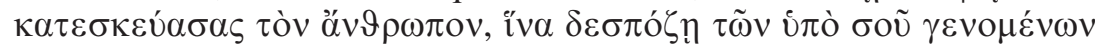
$\kappa \tau \imath \sigma \mu \alpha \dot{\alpha} \omega v^{43}$. The stress is not on human sovereignty, but on the $\kappa \tau 1 \sigma \mu \alpha \dot{\tau} \omega \nu$ of the second part, who are created by God and whose nature is clearly of the created not divine order. The quotation is introduced by an explicit formula, indicating the provenance of the passage: $\dot{\varepsilon} v \delta \grave{\varepsilon} \tau \tilde{\eta}$

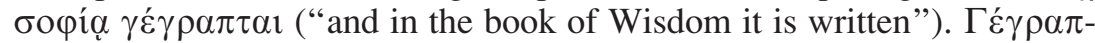
$\tau \alpha \mathrm{l}$ is a very usual formula to introduce a quotation ${ }^{44}$. So in this regard there is no difference with the "canonical books". Moreover the quotation stands in a series of citations. Besides Wisd 9,2 the following texts are brought to the fore: Ps 103,24; Rom 8,22; Rev 8,9 and 1 Tim 4,4; Mk 10,6; Deut 4,32 and, finally, a long quotation from Col 1,15-16, all "canonical books". By placing Wisd 9,2 among these other citations,

41. $C A$ II, $44-47$ ( $P G$ 26, col. 240-248).

42. $C A$ II, 47 ( $P G$ 26, col. 245-248; ET: A. ROBERTSON (n. 39), p. 374.

43. $C A$ II, 45 ( $P G$ 26, col. 243-244): "And in your wisdom fashioned men to have sovereignty over the creatures which you made".

44. Cf. G. MüLleR, Lexicon (n. 10), col. 262. 
Athanasius clearly treats Wisdom on an equal footing with the "canonical" writings.

\section{5. "A Multitude of Wise Men is the World's Salvation" (Wisd 6,24) in Contra Arianos II,79}

After the long section on Prov 8,22 and a short excursus on Prov 8,2325, the second book of Contra Arianos ends with a meditation on divine Wisdom (78-81). This Wisdom of God, synonymous to the Logos, is called the Creator of all things. God is said to be pleased to send His Wisdom to earth, to impart a semblance of its image on all creatures, so that what was made would be worthy of Him. This means that it is possible to recognize, in and through Creation, the Word of God and via the Logos the Father himself. On the other hand it follows that divine Wisdom is present in the created world. In the string of proof texts Athanasius adduces to argue for this presence of divine Wisdom in the created world, he alludes to a text from the Wisdom of Solomon. "Is there any wisdom in the creatures or not", he asks the Arians rhetorically. If they deny this, Athanasius asks, what then with the complaint of the Apostle: "Because in the Wisdom of God the world does not recognize God by its wisdom" (1 Cor 1,21a)? And if there is no wisdom in the created world, as Athanasius has the Arians say, "How is it then possible that "a multitude of wise

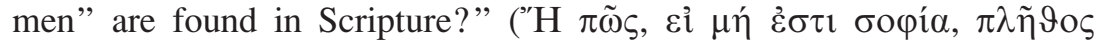
$\sigma о \varphi \tilde{\omega} \nu \dot{\varepsilon} \nu \tau \tilde{n} \Gamma \rho \alpha \varphi \tilde{n} \varepsilon \dot{\varepsilon} \rho \hat{\sigma} \sigma \kappa \varepsilon \tau \alpha 1 ;)$.

As he writes nothing more than $\pi \lambda \tilde{\eta} \vartheta$ o $\sigma \circ \varphi \tilde{\omega} \nu$, one might think that Athanasius merely refers in general to the examples of wise men present in the Bible (e.g., the many prophets) without having the text of Wisd $6,24 \mathrm{a}$ in his mind. But since the text here is in a chain of proof texts, we tend to see in it an explicit and deliberate allusion to Wisd 6,24a: "A multitude of wise men is the world's salvation" $(\pi \lambda \tilde{\eta} \vartheta \circ \varsigma \delta \dot{\varepsilon} \sigma o \varphi \tilde{\omega} v$ $\left.\sigma \omega \tau \eta \rho i ́ \alpha \kappa o ́ \sigma \mu \mathrm{v}^{45}\right)$. Moreover, this fits neatly in the context: the multitude of wise men are presented as an embodiment of the immanent presence of Wisdom. Since the Logos mediates God's salvific act, the multitude of wise men as the embodiment of Wisdom/Logos, have become salvation for the world. And this is precisely what is said in the part of Wisd 6,24a that Athanasius did not quote. Note also that the text is styled as belonging to Scripture and that it, with a number of other proof texts, supports a theological argumentation. The following quotations include Prov 14,16; Prov 24,3 and Eccles 8,1; 7,10, all "canonical books" 46 .

45. LXX-text, cf. J. ZIEGLER (ed.), Sapientia Salomonis (Septuaginta. Vetus Testamentum Graecum auctoritate Societatis Litterarum Gottingensis editum, XII/1), Göttingen, 1962, p. 115.

46. CA II, 79 (PG 26, col. 313). 
Finally it is noteworthy that, as far as we know, no author before Athanasius has ever used this verse, one more indication for the thoroughness of Athanasius' Scriptural knowledge and his originality in this respect.

\section{The Book of Wisdom and the Holy Spirit in Athanasius (Wisd 1,5; 1,7 and 12,1 )}

Athanasius' theological endeavours and his most extensive theological treatises focused foremost on the double nature of the Son, who was of the same essence as the Father, and on the consequences this had for soteriology. His defence of the idea that the Son is in all respects like the Father and his ensuing defence of the catchword ómoov́rıs had to lead to a reflection on the place of the Holy Spirit within the Trinity. It was during his third exile (357-362) that Athanasius systematized his thinking on the subject of the Spirit. This pneumatological reflection found its main impetus thanks to an inquiry of his friend Serapion of Thmuis ${ }^{47}$. He had asked Athanasius' advice how to counter the arguments of a group of Christians in Egypt who accepted the divinity of the Son, but who, influenced by the ideas of Eunomius, denied that of the Spirit. Athanasius' First Letter to Serapion ${ }^{48}$ contains all the important arguments put forth by this group of Egyptian Christians as well as of Athanasius' response. The Letter, however, was too lengthy for pastoral use, so Athanasius agreed to write a shorter one. This answer to Serapion's request consisted originally of what we know now as the Second and the Third Letter to Serapion $^{49}$. The first part of this double treatise deals with the doctrine of the Son, which is, in Athanasius' view, an essential prerequisite for a sound pneumatology. In the second part Athanasius reiterates the argumentation of chapters 22-31 of his First Letter. The third reply to Serapion, the so-called Fourth Letter $^{50}$, probably originally contained only the first seven chapters, chapters $8-23$ being intended as a separate tractate on Mt 12,32. In these seven chapters, the Alexandrian bishop answers the pneumatomachian party's objections, which were mainly based upon chapters 15-21 of 1 Serap.

47. On Serapion see K. FITSChEN, Serapion von Thmuis. Echte und Unechte Schrifte sowie die Zeugnisse des Athanasius und Anderer (PTS, 37), Berlin - New York, 1992. On pp. 135-147 Fitschen offers a basic discussion of these writings, including a convenient summary of their contents. M.A. HAYKIn, The Spirit of God. The Exegesis of 1 and 2 Corinthians in the Pneumatomachian Controversy of the Fourth Century (Supplements to Vigiliae Christianae, 27), Leiden - New York - Köln, 1994, contains an important section on Athanasius and his role in the development of Eastern pneumatology (pp. 18-24 and 59103). He has good grounds for dating the correspondance between Athanasius and Serapion in 358-359 (pp. 59-60); Fitschen opts for 359-360 (pp. 146-147).

48. $P G$ 26, col. 529-607.

49. $P G$ 26, col. 607-637.

50. $P G$ 26, col. 637-676. 
The $\tau \rho о \pi \imath \kappa o i ́$, as Athanasius styles his and Serapion's opponents, have basically the following arguments ${ }^{51}$. One part of their argumentation against the divinity of the Spirit is Scriptural. The most important text involved is: "For behold, I am he who strengthens the thunder, and creates the wind $(\pi v \varepsilon \tilde{v} \mu \alpha)$, and proclaims to men his Christ, forming the morning and the darkness, and mounting on the high places of the earth, The Lord Almighty is His name" (Amos 4,13). Athanasius answers that

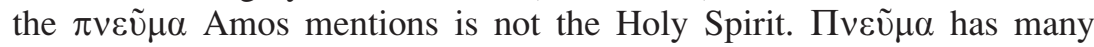
meanings, it does not necessarily designate the Holy Spirit. Nor does the reference to Christ in Amos 4,13 enhance the argument of the pneumatomachians of Thmuis: the text speaks of the human spirit, which is newly created, renewed by the coming of Christ. So, according to Athanasius, Amos 4,13 should not be interpreted as speaking of the Holy Spirit, but of the human spirit. Another verse adduced by the Tropici is 1 Tim 5,21, the relevant part of which is: "Before God and Christ Jesus and the angels who are his chosen, I solemnly charge you...". The Tropici interpreted this text as meaning that the Spirit belonged to the angels. They call on Zach 4,5 to support this. Athanasius counters this argument by saying that Scripture states nowhere that the Spirit is an angel. He counters the quotation from 1 Tim by saying that, even when the Spirit is not explicitly mentioned beside to the two other divine persons, his presence should be assumed (1 Serap 3-14). Besides these Scriptural proof texts the Tropici also brought forward an argument ex absurdo: if the Spirit has a divine status, what is his place within the Trinity: is he also a Son of the Father and therefore a brother of Christ, who is then no longer an Only begotten? Or is the Spirit, not of the Father but of the Son, which makes him a Grandson of the Father? Athanasius answers that it is wrong to use human relationships as models for the unsearchable mystery of the intratrinitarian relationships (15-20). He goes on to explain his own ideas once more, buttressing them with a thorough examination of the Scriptures: the Spirit is not a creature. He does not belong to the created world, but finds his origin in God. He sanctifies and renews creatures, but is not one of them. Through the Spirit, human beings can partake of the being

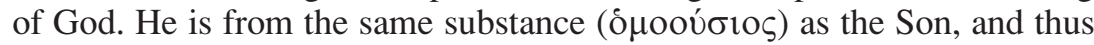

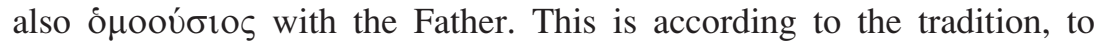
which baptism, performed in the name of the Trinity, bears testimony. The Tropici do not acknowledge a trias, but only a dyas. They risk the effectiveness of their baptism. Athanasius ends this treatise by citing further texts proving the unity of the Godhead (21-33). This is the broader context in which Athanasius uses the verses of Wisdom under discussion.

51. Besides the works by Fitschen and Haykin (n. 47) see also the articles by A. Heron, Zur Theologie der "Tropici" in den Serapionbriefen des Athanasius, in Kyrios 14 (1974) 3-24 and R. Smythe, Amos 4,13 (n. 4). 
1 Serap. $26^{52}$ cites Wisd 1,$5 ; 1,7 ; 12,1$. In this chapter Athanasius argues for a divine nature for the Spirit. In a first step he argues that the Spirit's nature is unchangeable, immutable and incorruptible. To support

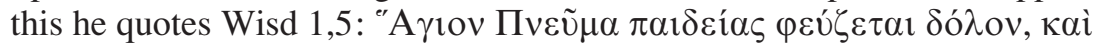

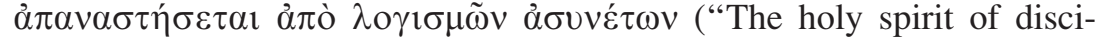
pline will flee falsehood; he cannot stay in the presence of unreason, and will withdraw at the approach of injustice"). The verse is introduced by a simple $\varphi \eta \sigma i$. It is followed by a quotation from a part of 1 Pet 3,4, with an introductory formula indicating the provenance of the verse. The conjunctive кaí links the quotation from the "canonical" 1 Pet 3,4 to that from Wisd 1,5. This clearly puts them on the same level.

The citation from 1 Peter is followed by another from the Book of

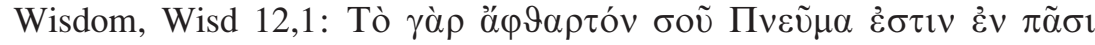
(for your incorruptible breath/spirit is in every one of them (sc. in all things created by the Lord). The word $\alpha \varphi \vartheta \alpha ́ \rho \tau o \varsigma$, common to 1 Pet 3,4 and Wisd 12,1 links the two verses. He goes on by citing 1 Cor 2,11 and James 1,17 . Then he reverses the argument to show that, contrary to the Spirit, created beings, including the angels, are changeable and therefore do not have a divine nature.

In a second step, still in the same chapter 26 of his First Letter to Serapion, Athanasius marks another difference between the divine Spirit and creatures: the Spirit fills the entire universe, whereas all creatures (the sun, the moon, the stars, the clouds, human beings, the angels) have their own place or boundaries. Though an introductory formula is lacking, this is an

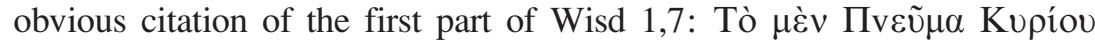

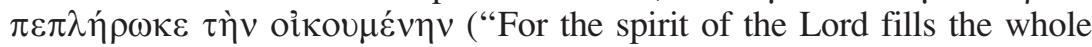
earth") and makes the point needed. This verse is followed by a citation

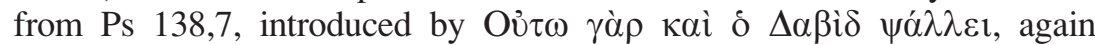
clearly linking both verses. "And again there is written in the Book of Wisdom", the text continues, introducing a second quotation from Wisd 12,1, which Athanasius had already used in the first step of his argument.

Finally in his Third Letter to Serapion, which summarizes the argumentation of 1 Serapion, Athanasius once again uses Wisd 1,7 and Ps 138,7 to defend the divinity of the Spirit by arguing that creatures have determined places while the Spirit is omnipresent filling the entire universe ${ }^{53}$.

The First Letter to Serapion was not the first time Athanasius used Wisd 1,5. He quoted this text in his Third Festal Letter, issued in $342^{54}$,

52. $P G$ 26, col. 589-594.

53. Cf.3 Serap. 4 (PG 26, col. 632).

54. FL III, nr. 4. This Letter is preserved only in its Syriac version. For the Syriac text see W. Cureton, (ed.), The Festal Letters of Athanasius of Alexandria, London, 1848, p. 26-32. An English translation of the Syriac original is to found in A. RoBERTSON, Athanasius (n. 39), pp. 512-515. The chronology of the $F L$ is a difficult matter because the order and transmitted date of the corpus of the Festal Letters do not go back to Athanasius 
albeit not as an argument for the divinity of the Spirit. In this Letter, Athanasius sketches for his flock the image of a diligent servant of the Lord. This is someone who profits greatly from the grace given him and who does not deliver himself to the lusts of the world. As examples of such diligent servants of the Lord, filled with His Spirit, he cites Moses, Paul and Jeremiah. To illustrate Paul's exemplary attitude, Athanasius quotes his exhortation to the Thessalonians not to let grow cold the grace of the Spirit bestowed on the Christians: $\tau$ ò $\pi v \varepsilon \tilde{u} \mu \alpha \mu \grave{\eta} \sigma \beta \varepsilon \dot{\varepsilon} v v v \tau \varepsilon$ «o not extinguish the Spirit" (1 Thess 5,19). This does not mean, Athanasius hastens to add, that the Spirit is placed in human power. Rather it means that the Spirit shuns these bad and impure men, that he stays away from sinners no longer filled with divine grace, who do not partake of Christ, who try to extinguish the Spirit, persecuting him with their unholy deeds. To sustain this, Athanasius cites, without any introductory formula, Wisd 1,5: "The holy spirit of discipline will flee falsehood; he cannot stay in the presence of unreason, and will withdraw at the approach of injustice".

To conclude this section we can say that the quotations from Wisdom are nowhere unequivocally introduced as Scripture. On the other hand we have had ample opportunity to see Athanasius treating his quotations from Wisdom on an equal footing with those from the "canonical books". In some cases the quotations from Wisdom and from the "canonical books" are closely linked. Finally, it is clear that citations from Wisdom are used to support theological reflection and are important elements in his argumentation in defence of the divinity of the Spirit.

\section{Conclusion}

The first goal of this article was to highlight the variety in Athanasius' use of the Scriptures ${ }^{55}$. A study of the borrowings from the Book of

himself, but are the results of an editorial process that ended much later. This editor ordered and dated each Letter on the basis of the Easter date it contains. Sometimes however Easter fell in different years on the same day, which means the editor might have assigned wrong dates to some Letters. Therefore the date of the $F L$ is open to revision. With regard to $F L$ III, for which the transmitted date is 331, this insight in the genesis of the corpus of $F L$ removes two difficulties: (1) Why does FL III mention a fast of forty days, whereas I, IV,V and XIV indicate that the fast began on the Monday of the Holy Week? It is not logical to assume a change in custom in Alexandria. (2) FL III refers to Athanasius' experiencing some tribulations that do not fit the situation of the year 331. FL III can better be assigned to 342 or 353 , when Easter fell on the same date (11 April) as in 331. Given the tribulations Athanasius mentions, 342 is the better choice. Cf. R. LoRENZ (ed.), Der Zehnte Osterfestbrief des Athanasius von Alexandrien. Text, Übersetzung, Erlaüterungen (BZNW, 49), Berlin, 1986, pp. 20-39; A. Camplani, Le Lettere Festali di Atanasio di Alessandria. Studio storico-critico (Unione Accademica Nazionale. Corpus dei Manoscritti Copti Letterari), Roma, 1989, p. 149-150; T.D. BARNES, Athanasius and Constantius (n. 12), pp. 183-192.

55. At the end of this article it might be convenient to give a complete list of references to the passages where Athanasius borrows from Wisdom: Wisd 1,5 in FL III,4 and 1 Serap 
Wisdom that he used in the context of a theological argumentation shows that he uses a great variety of passages. As regards the purpose of these borrowings, we have seen that quotations from the Book of Wisdom are used on a variety of theological issues: the refutation of pagan idolatry, original sin, the possibility to know God through creation, the uncreated essence of the Son, the divinity of the Spirit.

We also saw that, at least with regard to the Book of Wisdom, there is no difference between "canonical books" and books to be read to the catechumens. This equality in use between the "canonical books" and the books to be read to the catechumens can be concluded from the following assessment regarding his use of Wisdom: (1) Often the borrowing from Wisdom is a quotation, introduced with a similar formula as the quotations from "canonical books" (e.g., $\varphi \eta \sigma i ́$, or $\gamma \varepsilon \dot{\varepsilon} \gamma \rho \alpha \pi \tau \alpha$, or a more precise indication); (2) The borrowing from Wisdom appears in a series of quotations, among them also passages from "canonical books". Sometimes there is a clear link between the two borrowings, e.g., the conjunction Kaí; (3) The quotation from Wisdom is used as proof text to support a theological argumentation. If Athanasius had not considered a book to be read to the catechumens on equal footing with the "canonical books", he would not have used it to support a theological argumentation. These three conclusions confirm that there is absolutely no difference in his use of the two categories. Athanasius clearly valued the writings of both categories on an equal level.

\section{SUMMARY}

1. Wisd 14, 12-21: Against Pagan Idolatry in Contra Gentes (352-355)

2. Incorruptibility and Immortality in De Incarnatione Verbi 4-5 (355-358)

3. Wisd 13,5: Traces of the Creator in the Visible World (358-361)

4. "Sovereignty over the Creatures" (Wisd 9,2) and "He Created" in Contra Arianos II, 45 (361-363)

5. "A Multitude of Wise Men is the World's Salvation" (Wisd 6,24) in Contra Arianos II,79 (363-364)

6. The Book of Wisdom and the Holy Spirit in Athanasius (Wisd 1,5; 1,7 and 12,1) (364-367)

Conclusion (367-368)

Elfnovemberlaan 36

Johan LEEMANS

B - 3010 Kessel-Lo

26; Wisd 1,7 in 1 Serap 26 and 3 Serap 4; Wisd 1,11 in Apologia Secunda 3,4 and Apologia ad Constantium 5,20; Wisd 2,21 in Historia Arianorum 71.3; Wisd 2,23-24 in DIV 5; Wisd 3,5-7 in Apologia de fuga sua 19; Wisd 6,18 in DIV 4; Wisd 6,24 in CA II, 79; Wisd 7,27 in FL I, 1 and FL X, §4a; Wisd 9,2 in CA II, 45; Wisd 12,1 in 1 Serap 26; Wisd 13,5 in $C G 44$ and $C A$ II, 32; Wisd 14,12 in $C G$ 9; Wisd 14,12-21 in $C G 11$; Wisd 14,21 in CG 17 . 